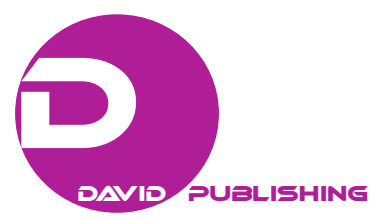

\title{
Jade Huang and Chinese Culture Identity: Focus on the Myth of "Huang of Xiahoushi”*
}

\author{
TANG Qi-cui, WU Yu-wei \\ Shanghai Jiao Tong University, Shanghai, China
}

\begin{abstract}
This paper focus on the myth of “Huang of Xiahoushi” (夏后氏之璜), focusing on the distribution of Jade Huang (玉璜) since the early neolithic and its process of pluralistic integration. The paper explores the story of ethnic group, cultural identification and the significance of Jade Huang in the discourse construction of etiquette civilization behind the mythic narrative based on multi-evidence method and the local meaning of literature in ancient Chinese context.
\end{abstract}

Keywords: Jade Huang, Huang of Xiahoushi, unified diversity, Chinese identity, etiquette civilization, multi-evidence method

\section{Introduction}

Modern archeological relics including potteries, jades and bronzes bring back the lost history; the process of how Chinese unified diversity took shape in general and the great tradition of jade culture in eight thousand in particular. The handed-down documents echo each other at a distance provide solid evidences for the origin of civilization of rite and music and the core values based on jade belief. Jade Huang is an important one of it. It is illuminated by numerous records about Jade Huang in ancient literature, as well as a large number of archaeology findings past 7,000 years. The paper seeks to focus on the following questions: what is the function of Jade Huang in historic and prehistoric period? Moreover, what is the function of "Huang of Xiahoushi”, which belonged to emperor and symbolized special power in historic documents and myths and legends in ancient china?

\section{Jade Huang: Etiquette and Literature}

Jade Huang (Yu Huang, Semi-circular/annular Jade Pendant) is a type of jade artifact which is seemed to be remotely related to etiquette and literature. If it were defined with western academic fashion, no wonder it would be absurd. We should explain its Chinese literary meaning, and put it in a context of Chinese etiquette, value system and aesthetic system. Huang made of high-quality jade is bound up with these issues. This concealed clue exists in literary and practice form of obsequies, and related encoding character configuration.

\footnotetext{
* Acknowledgements: This paper is suported by China National Social Science Foundation "A Study on the Relationship Between the Myth of Ritual Vessels in Rites of Zhou and the Construction of Chinese ritual discourse" (3CZW022). Here I'm grateful to Wu Yuwei for her help to translate the article and to An Qi for her timely help to revise and polish it.

TANG Qi-cui, Ph.D., is an Associate Professor in School of Humanities at Shanghai Jiao Tong University, Her research fields cover literary anthroplogy, ritual and myth, jade culture and cultural identity.

WU Yu-wei, is a Senior Student at Shanghai Jiao Tong University, and will study Anthropology in Chinese University of Hong Kong in postgraduate stage. She is devoted to the jade culture research in recent years.
} 
According to Xu Shen (Eastern Han Dynasty 25-220) recorded in Analytical Dictionary of Characters (说 文解字, Shuo Wen Jie Zi): Etiquette is like walking with shoes, one should serve their holy spirit to get blessing (禮者, 履也, 所以事神致福也). At first Etiquette (禮) was written as “貫” in Oracle (inscriptions on bones or tortoise shells of the Shang Dynasty: c.1600-1046BCE), which means the artifact serving as the sacrificial vessel. The character is like a vessel with two jades in it. The vessel to place jade for holy spirit is written as Thus the character “醴” means serve alcohol for the holy spirit, and “禮” means service for the holy spirit (像二玉在器(即豆)之形, 即盛玉以奉神人之器谓之豊, 推之而奉神人之酒谓之醴, 奉神人之事通谓 之禮). ${ }^{1}$ The subject of the etiquette ceremony is “㡟”, “體” (Body). In a word, the character “豊” carried double meanings of sacrificial vessel at first: One is the sacrificial vessel (jade or pottery), with the purpose of serving holy spirit and wish for blessing, the other is mankind. ${ }^{2}$ The internal relation between jade and the funeral practice of jade from prehistoric times to late Qing Dynasty and glyph on bones or tortoise shells and bronze objects like Body (體), Rite (禮), Sage (聖), King (王), Shaman (巫), all witness the long-standing value of unified diversity "bdoy, etiquette, jade and ethics”. ${ }^{3}$ Just like The Book of Rite (礼记) repeatedly claimed about the relation between "body, etiquette and jade" and "rites of passage, kingship, holy spirit":

A gentleman wears jade anytime except for an emergency. The behavior would not affect the etiquette. Notes and commentaries of Kong Yingda: Jade means baldric (Jade worn by gentleman). In early period of China, jade is the symbol of gentleman's virtue and amulet, so they always wear jade to manifest their lofty virtue. ${ }^{4}$

The sons of noble had gone to primary school to learn the basic techniques such as six-etymology, arithmetic, etc., and practiced basic etiquette when they were 8 years old in ancient time. When they turned 15 years old, they had gone to college to receive formal education: Songs (诗), History (书), Rites (礼), Musics and Dances (乐), Changes (易), and the techniques of Shooting and driving (射御) etc., and began to wear jadeware. Walking with the wear-jades clink and riding with horse-bells ringing in harmony and concord, which kept them away from all the evil. The wear-jades consisted of pair of Heng upper and pair of Huang under jointed with belt, jade beads and other geometrical or animal-shaped jadeware. Because of walking in harmony with the music of Cai Ci (采茨) and skelping in harmony with Si Xia (肆夏), the wearable jades would clink rhythmically with their feet and body moving in harmony with the music and ritual. ${ }^{5}$

As The Book of Rites refers, the jade would not become artifacts without being carved. People would not be familiar with virtue without being educated (玉不琭不成器，人不学不知道). According to the Qi Ao (淇奥) in The Book of Songs, the process of learning to become a gentleman is equivalent of refining jade; and the perfect gentleman was like precious jade such as Gui and Bi (有匪君子, 如切如磋, 如琢如磨。有匪君子, 如 金如锡, 如圭如璧). The mixture of two metaphors is quite clear: the manufacture of jade artifacts equals to cultivating one's moral character, and wearing jade is referred to practice of etiquette. The four cardinal virtues that humanity (仁), justice (義), propriety (禮) and wisdom (智) could gradually interiorize and embody in behavior, and eventually make gentleman possess the quality as precious jade which gentle, sincere, modest, agreeable, holy and majesty (“言念君子, 温其如玉”) by learning etiquette and literature at home (居习礼文), wearing jade accessories (amulet) in walking (行鸣佩玉), practicing etiquette what one preaches (身体力行).

\footnotetext{
${ }^{1}$ Wang Guowei, 观堂集林 (Guan Tang Ji lin, Selected Works of Wang Guowei), Peking: Zhonghua Book Company, 2006, p. 291.

2 Tang Qicui, Li (禮, Etiquette), Ethnic Arts Quarterly, 2014(3), 22-29, 35.

3 Tang Qicui, Body and Etiquette: Practicing Etiquette by Wearing Jade and Confucian Myth, The Journal of Bai Se College, 2011(3), 12-18.

4 Ruan Yuan, Commentaries on Thirteen Classics, Peking: Zhonghua Book Company, 2003, p. 1259.

${ }^{5}$ Wang Pinzhen, Commentaries on the Book of Rite of Dai De, Peking: Zhonghua Book Company, 1983, p. 61.
} 
Lao-tzu claimed that sage wore worn clothes while wore precious jade (被褐怀玉). Confucius compared himself to precious jade that expect a high bid. Mencius compared Confucius to the holy incarnation of jade. All of them revealed the etiquette value of jade. According to Baofu Pian (保傅篇), Jade Huang was the major part of the ritually and sacrificial wearing of jade accessories. As was found in some Zhou Dynasty sites like Guo State cemetery (虢国墓地) and Jin Hou cemetery (晋侯墓地) by archaeologist in 20th century, and some Neolithic site like Ling Jiatan site (凌家滩遗址) and Liangzhu site (良渚文化遗址), the set of Huang witness the fact that tradition of wearing jade could trace back to the early period of civilization (see Figure 1).

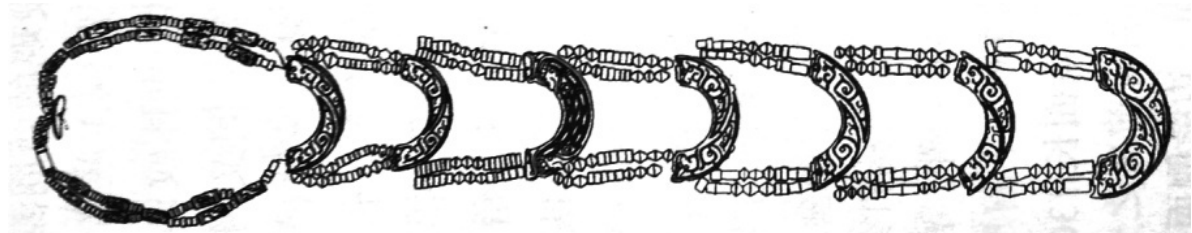

Figure 1. Seven set of wearing Jade Huang of West Zhou Dynasty in the vassal King Guoji’s tomb.

This kind of value and belief also exists in Chinese character configuration and the related literature view. In oracle-bone inscription, the character (文) was written as $\hat{x}$, 产, representing a standing man with a tattoo on the chest or a necklace. It was often used in name of people and place or the ancestral honorific title of saints and emperors like Wenzu (“文祖”),Wen Shi (“文室”), Wenwang (文王) and etc., inscriptions on ancient bronze objects of Zhou Dynasty inherit the features of oracle-bone inscription. Most of them were used to praised the political and military achievements of Wen Emperor, such as “Yue Gu Wenwang” (曰古文王) in Qiang Plate (墙盘). Apart from that, the character (文) was often used to refer ancestor with great political and military achievements, such as “wenren” (文人) in Zhui Gui (追笽), “wenkao” (文考) in Shi Hai Gui (师害 篮). ${ }^{6}$ The configuration of character (文) used the meaning of ornamentation, which may trace back to the witchcraft ceremony aiming at counteracting evil force or appeasing the spirits. Twenty thousand years ago, the Peking Man in Zhoukoudian (周口店), wore the animal teeth and stone-made ornaments and used hematite to protect their bodies when they were dead. ${ }^{7}$ Nowadays the Shamans of Elunchun (鄂伦春族) still wear “Enke” (made of agate, jade or bones) to perform god dance and vision quests ${ }^{8}$. Words (文字), wording (文辞), literary grace (文采), literature (文学) were expounded from the meaning of the ornaments of etiquette.

The Chinese word of literature first appeared in the phrase of four main character of ethics of The Analects of Confucius (论语). Zixia (子夏) and Ziyou (子由), apostles of Confucius, were good at literature, they were quite familiar with the etiquette system and ritual books, instead of the litterateurs in the modern sense. ${ }^{9}$ Inspecting the views on wen (文) in The Analects of Confucius (论语) like Confucius said, if the context was more than wording, the content would be rough. However, if the wording were more than the context, the content would be perfunctory. Thus you should improve both context and wording to become a gentleman (“子 曰: 质胜文则野, 文胜质则史, 文质涁樹, 然后君子”). If you study it from the text prototype, you would find it also originated from ritual ceremony, such as the oracle-bone character Ye (野, wilderness) was written as

\footnotetext{
${ }^{6}$ Huang Dekuan (Ed.), 古文字谱系疏证 (Anotation on the Geneology of Ancient Characters), Peking: Commercial Press, 2007, pp. 3806-3809.

7 Pei Wenzhong, The Culture of Zhoukoudian Upper Cave Man, Wenwu Chunqiu, 2002(2), 1-7.

${ }^{8}$ Guan Xiaoyun, Wang Honggang (Eds.), Investigation of Shaman Culture's remains in Oroqen People, Peking: Nation Press, 2010, p. 92.

${ }^{9}$ Liu Baonan, The Analects of Confucius, Peking: Zhonghua Book Company, 1990, pp. 441-442.
} 
“埜” to illustrate the shrine in the forest; The character Shi (史, historian) was written as “奴” to illustrate the gesture of carrying the holy craft to pray for the gods and preach their beliefs, which turns into the meaning of engraver and historiographer. ${ }^{10}$ The character Zhi (质, nature) consisted with Jin (斤, a kind of axe) and Bei (贝, shell), was transform from the shape of a precious shell in Nanhai, which was also a ritual object. The internal relation between the sentence "study of rites to demonstrate one's erudition as a scholar and a gentleman” (文质彬涁, 然后君子) and the holy ritual ceremony was clearly described in divinatory symbols of $\mathrm{Bi}$ in Books of Change (周易·贲卦): In order to observe the social issue, you should observe the astronomical phenomenon; in order to conquer the world mentally, you should observe the human culture (观 乎天文，以察时变; 观乎人文，以化成天下). The character of Bi (莹) consists of Bei (贝, cowry) and Hui (卉, various kinds of grass or ancient monetary unit of money cowry), means ornamentation and beauty (贲者, 饰 也 (序卦传)), 美也” (广雅) which can exchange with another character of Ban (斑) expressed by interlacing figure (交错为文). All the divinatory symbols of Bi (贲) were related to ornamentation, which refers to the grace of jade ornaments and the fine culture. The order of the world is classified by their own type. Category (类) become the final version of the feature of Wen (文). According to The Book of Rites, the Wen (文) in the ancient times indicated the grace of literature and music, the appearance of behavior, and the sound of the holy songs. In the world of ancient saints, "literature" and "humanities" are the two sides of an issue, so are "nature" and "culture". Thus all the forms of the human culture's expression are the form of Wen (文). ${ }^{11}$ The significance of literature relies in the dimension of human performance (文之为文, 恰在不断地“人文化成”) In this context, Wen (文) does not just refer to ornamentation, while Zhi (质) does not just mean simple. Instead, they were related to the cultural and belief context carved on the holy ornaments. Thus the oath with the holy ancestor or the oath made under the holy spirits' supervision were called Ze (则, rule). The content of it called essence (本质). Correcting the misconducts called Zhizheng (质正). When Wen (文) matches with Zhi (质), it is called fine appearing and gentlemanly (文质涁涁). Bin (涁) is also written as Bin (斌, ornamental), Ban (斑), which reflects difference and familiarity in the words configuration. This is the true meaning of respecting virtue and ethics.

The essence of Chinese character is pictograph. Seen from the perspective of semiotics, the Chinese character defines itself with Chinese language, picture, objects, and rituals. Chinese character originates from visual symbols like ornamentation on pottery, paintings on rocks. The Chinese character has the feature of pictogram, and also relates to physical symbol. ${ }^{12}$ Maybe it is precisely the feature of Chinese character that provides the clue to relate context to physical objects for contemporary scholars.

The prototype of Wen (文) character originate from tattoo or necklace, which are used to mark the nation, indicating the social status or protect the body from evil. The most valuable evidence provided by archaeology is the Jade Huang, the one that lasts more than seven thousand years. The first version of the character Huang (璜) was written as象, 秉, which looks like a standing man with a special tattoo on the chest. Thus Guo Moruo explained Huang (璜) as the abstract form of the ancient jade ornament (古玉佩之象形), and he also made a restored drawing of Huang (璜) (see Figure 2). ${ }^{13}$ However, all the 281 examples in Oracle-bone character did

\footnotetext{
10 Tang Qicui, The Ritual Relics and the New Evidence of the Historian Recording Ancestry: The Sorcery-History Roots of Confucianism and Taoism from the Myth of YuGui, The Journal of Philosophy and Culture, 2012(6), 41-63.

11 Zhang Zailin, Interpretation on "Wen”, Social Science Forum, 2010(13), 40-47, 64.

12 Huang Yaping, \& Meng Hua, Chinese Character Semeiology, Shanghai: Shanghai Ancient Books Press, 2001, pp. $143,144$.

13 Guo Moruo, Interpretation on "Huang”, in Guo Moruo, Explanations on Bronze Inscription, Peking: People Press, 1954, pp. 162-174.
} 
not refer to Jade Huang (玉璜). The character of Hong (虹, 凤, rainbow, dragons with two heads) has the most similar shape with Jade Huang was also not related to wearing Huang. But this does not stop ancient people from imagining the Huang and the rainbow. The most famous example is the myth of Confucius revision of Spring and Autumn Annals (春秋) and Filial Piety (孝经). When he was about to finish his work, he fasted and practice ritual to the Plough. Then a gust of red wind came from the heaven and transformed into Huang. ${ }^{14}$ Although it has a lot more to do with the history romance, the idea that the shape of Huang came from rainbow existed long time ago. The reason why it called Huang, Hong, and Gong, is because of their arched shape. ${ }^{15}$ The character Huang used the configuration of rainbow or two-heads dragon. The archaeologists proved that the objects of Huang existed in Hongshan site at least five thousand years ago, and transformed into a unified form (see Figure 3).
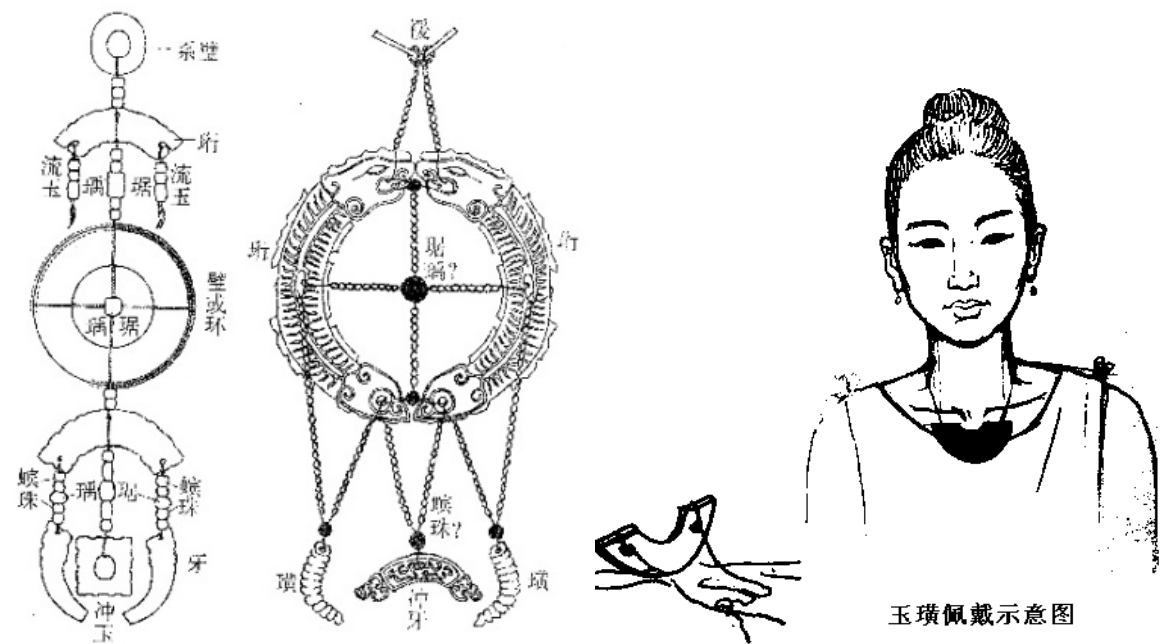

Figure 2. The form of wearing Jade Huang, drawn by Guo Baojun (left), Guo Moruo (middle), Qingpu Museum (right).

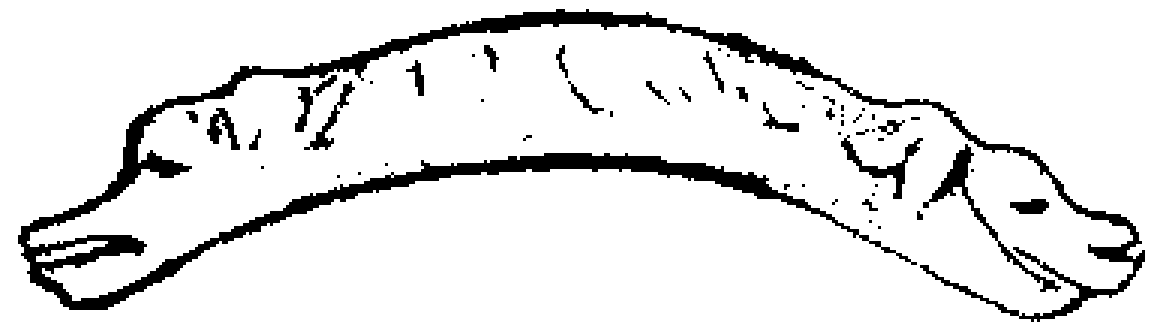

Figure 3. Drawing of two-heads dragon excavated from Kazuo Dongshanzui Site of Hongshan culture in Liaoning Province.

In inscriptions of ancient bronze objects, besides two obvious example of Jade Huang, most of them were the objects used to confer titles of nobility like zhuhuang (朱黃), youhuang (幽黃), conghuang (忽黄), jionghuang (问黄), jinhuang (金黄), etc., Thus Tang Lan suggested that Huang (黄) in inscriptions of ancient bronze objects has nothing to do with Jade Huang, but with the belt of the jade ornaments (系佩玉之带) ${ }^{16}$ The

\footnotetext{
14 Li Fang (Ed.), Taiping Imperial Encyclopaedia, Shijiazhuang: Hebei Education Press, 1994, p. 130.

15 Ren Jifang, Chinese Etymology, Chongqing: Chongqing Press, 1992, p. 65.

16 Tang Lan, New Explanation of ZhuFu, CongHeng, YuHuan, Yushu in Maogong Ding (Tripod), in Tang Lan's Selected Works about Bronze Inscription, Peking: ZiJin Cheng Press, 1995, pp. 86-93.
} 
jade ornaments has a unified name of Pei (佩), Huang (黄) has another meaning. ${ }^{17}$ But there were not enough literary evidence to discuss whether Huang (黄) refers to the set of jade ornaments except for archaeological evidence. I will discuss this later.

What is the relationship between literature and cultural relic? The archaeologist Colin Renfrew pointed out in his Prehistory:

People create material symbol to create the sensible reality... We could not directly touch the myth in prehistory period. However, we could in deed learn the early social actions and try to connect these actions to the reality by the trace of the material. ${ }^{18}$

Thanks to the reappearing of the materialistic symbol, the long disappeared nations could narrate their glorious past and their history, belief and life. Historical records, even the most abundant ones of East Asian countries, were unable to contain the content of Hongshan (红山), Liangzhu (良渚), Shimao (石峁), Qijia (齐 家), Lingjiatan (凌家滩), Shijiahe (石家河), Sanxingdui-Jinsha (三星堆-金沙). Cultural relics speak in the place where texts kept silent. In our days and age, we witness how Chinese nation transformed from diversity to unity. The jade, with its life expand more than eight thousand years, functions the evidence of the pluralistic integration of Chinese nation and literature producing.

\section{Jade Huang: The Evidence of the Pluralistic Integration Process of the Chinese Nation}

What is Huang? As demonstrated in the Jade part of Analytical Dictionary of Characters (说文解字), Bi (璧) is a ring made of good jade. Yuan (瑗) is a Bi with a big hole. As Er Ya (尔雅) put it, when the brim was bigger than the hole, it was called Yuan. While if the hole is bigger than the brim, it was called Bi. And if the hole was the same wide as the brim, it called Huan. Huang is half of Bi. According to Duan Yucai: Zheng Xuan explain Rites of Zhou (周礼) that the circle Bi is the symbol of heaven (璧園象天). The half Bi called Huang (半璧曰璜), is the symbol of inventory in winter, there were nothing on the ground except half the sky (象冬令 闭藏, 地上无物, 唯天半见). According to Da Dai Liji (大戴礼记), a pair of Huangs are under the set of jade, both of which were half circle and looks like Huang but smaller. $)^{19}$

According to this earliest dictionary's explanation, the shape of Huang is similar to jade artifacts like Bi (璧, a round flat piece of jade with a hole in its center), Yuan (瑗), and Huan (环, ring). In another word, only by studying the shape and structure of Bi (璧), Yuan (瑗), Huan (环), could we get a closer look at Huang (璜). The picture and real objects are obviously more definite than literary descriptions. China's leading archaeologist of his time, Xia Nai (夏䱦), suggested to entitle the objects according to the description in documents and the real objects. ${ }^{20}$ But the problem is that the descriptions in the documents often did not match with the real objects. Regarding the shape of the objects, the documents often recorded the standard objects, while the relics differ from different places and dynasties. In spite of that, the basic structure is the same-Arc strip ends drilling with two holes on both ends in order to hang (see Figure 4).

\footnotetext{
17 Sun Qingwei, The Studies on the Rule of Jade Using in Zhou Dynasties, Shanghai: Shanghai Ancient Books Press, 2008, pp. 182-184.

${ }^{18}$ C. Renfrew, Prehistory: Memory of Human Mind (Zhang Mingling, trans.), Taipei: Owl Press, 2009, p. 203.

19 Duan Yucai, Annotation on Shuowenjiezi, Shanghai: Shanghai Ancient Books Press, 1981, pp. 10, 12.

${ }^{20}$ Xia Nai, The Classification, Denominate and Function of Jadeware of Shang Dynasty, Archaeology, 1983(5), $455-467$.
} 

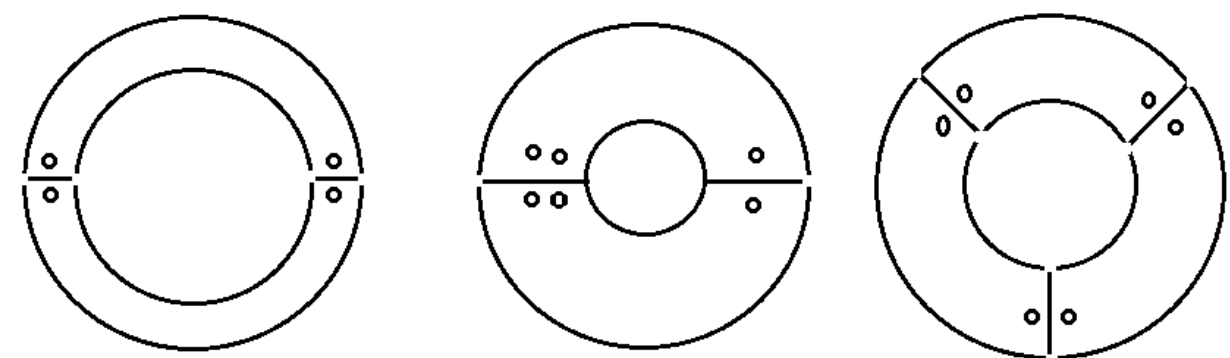

安徽含山凌家滩文化环与半环形璜 山西芮城清凉寺仰韶文化璧与半璧形璜 青海民和喇家遗址济家文化扇形璜联璧

Figure 4. The drawing of half-Huan, half-Bi and fan-shaped Huang excavated from ancient culture site.

People of Han Dynasty regard Huang as half of $\mathrm{Bi}$, which first appeared in prehistoric cultural sites such as Songze (崧泽), Lingjiatan (凌家滩), Xuejiagang (薛家岗), Liangzhu (良渚) etc., all appeared in the lower reaches of Yangtze River (see Figure 5). Liangzhu culture in its late period is typical. Then it was expanded into the late Yangshao culture of Ruicheng temple sites (茌城清凉寺遗址).

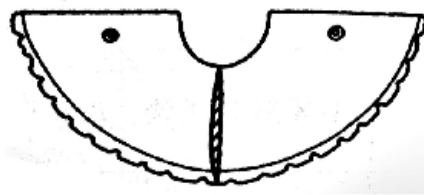

安徽凌家滩87M11出土花边璜

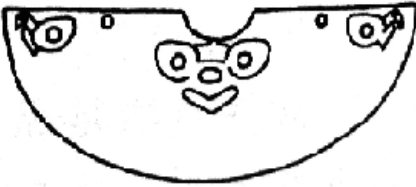

良渚反山M23出土

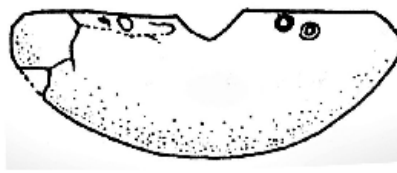

安徽薛家岗M32出土

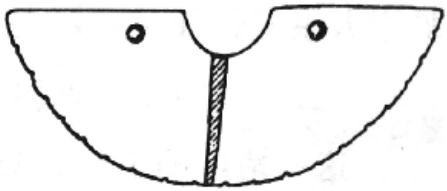

长江中游大湀M140出土

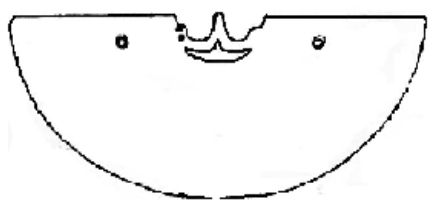

长江下游良渚瑶山M11出土

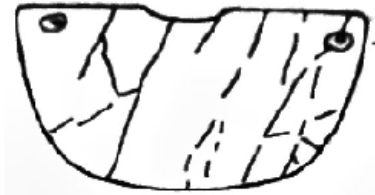

黄河下游江苏花厅M36出土

Figure 5. The drawings of half-Bi shaped Huang in the middle and late of Neolithic period.

It was hard to say when and where Huang first emerged. So far the archaeological evidence indicates that Jade Huang first appeared in lower reaches in Yangtze River seven thousand years ago. After that, it appeared in middle reaches of Yangtze River, lower and middle reaches of Yellow River, and Liao River and the Pearl River Basin. The Jade Huang from T302 site in Xiao Shan Kuahuqiao (萧山跨湖桥) is the earliest Jade Huang so far. $^{21}$ The Hemudu (河姆渡) site in Yuyao’s (7,000-5,300 years ago) fourth cultural layer contains jade Huang. ${ }^{22}$ Moreover, 6,000 to 4,500 years ago, lower reaches of Yangtze River produced the most abundant and concentrated Jade Huang, among which the Beiyinyangying (北阴阳营) Site in Nanjing (about 6,000-5,500 years ago), Lingjiatan (凌家滩) Site in Hanshan (about 5,300-5,200 years ago), Liangzhu Site in Yuyao (about 5,300-4,300 years ago) were the most prevalent area. About 6,500 years ago, Huang appeared in Daxi Culture Circle (大溪文化圈) in middle reaches of Yangtze River (Chengtoushan in Lixian, Gaomiao in Hongjiang, Yanhjiawan in Yichang, Guihuashu in Songzi, Zhongbao Island, Qingshui Shoal, Daxi in Wushan). Then the spread of Huang extended to Qujialin Culture (屈家岭文化, about 5,100-4,500 years ago) and finally declined

\footnotetext{
21 The Institution of Archaeology of Zhejiang Province, Neolithic Sites in XiaoShan Kuahuqiao, The Journal of the Institution of Archaeology of Zhejiang, Peking: Chang Zheng Press,1997, pp.17-20.

22 The Institution of Archaeology of Zhejiang Province, Hemudu: Report on Archaeological Excavations of Neolithic Site, Peking: Cultural Relics Press, 2003, pp. 78, 262, 320, 356.
} 
in Shijiahe Culture (石家河文化, about 4,500-4,000 years ago). About 6,000 years ago, a few Jade Huang and Huang-shaped ornaments had been discovered in Dawenkou Cultural Circle (大汶口文化圈) in lower reaches of Yellow River (Liulin Site in Jiangsu Pixian, Huating in Xinyi, Xiaoshan Jinzhai County in Anhui, Zaozhuangjianxin in Shandong, etc.), Yangshao Cultural Circle (仰韶文化圈) in middle reaches of Yellow River (Banpo in Xi'an, Longgang temple in Nanzheng). About 5,500-4,500 years ago, a few Jade Huang randomly scattered in Liao River region in north-east China, of which the northernmost was in Yilanwokenhada Site (依兰倭肯哈达遗址) in Heilongjiang province. About 4,500-4,000 years ago, Huang and Huang-shaped ornaments had been discovered in Shixia Site (石峡遗址) in Guangdong, of which the westernmost was in Karuo Site (卡若遗址) in Tibet and Minhelajia Site (民和喇家遗址) in Gansu. About 4,300 years ago, Jade Huang became one of the most important ritual objects in Longshan cultural Site (龙山文 化遗址) in Yellow River region, ranging from Shandong, Shanbei and Jinnan such as Tao Temple (陶寺), Xinhua (新华), Shimao (石峁), Hougang (后岗) and Qijia Cultural Circle (齐家文化圈) in north-west China. ${ }^{23}$ Thus some scholars suggested that the early nation possessing Jade Huang spread their offspring by means of water transportation such as Taihu Lake (太湖), Yangtze River (长江), Huai River (淮河) and Yellow River (黄河). The nation spread to the whole China by means of material exchanging, culture spreading, military conquers. $^{24}$

In addition, it remains a question whether Jade Huang originate from one place or several places. According to the structure and the placement of the Jade Huang relics so far, the only thing that could be sure is the trend of unity in the production and usage of Jade Huang 7,000 years ago. Such as the earliest appeared Jade Huang with a serrated edge in Lingjiatan site (see Figure 5), the spread of Huang got to the northeast of the transferred to yingpanshan (营盘山), Taihu Lake Jin Ping Cun (太湖金坪村), the arrival to the southwest, and along the Yangtze River upstream to the West arrived in Wuxue Gushan (武穴鼓山), Badong Li Jia Wan (巴东李家湾) until Wushan Daxi (巫山大溪). All of these were found on the chest of the host of the tomb, and the bigger the structure, the higher the class and the less the amount far away from the headstream (generally speaking, only one for a site). This indicates that 6,000-5,500 years ago half-Bi shaped Jade Huang with a serrated edge played a special role in the process of social differentiation and cultural spread of Yangtze River Region. ${ }^{25}$ In terms of shape and structure, the most typical type is half-ring shaped, bridge shaped, half-Bi shaped, and fan-shaped. The half-ring shaped Huang first appeared and lasted long in Kuahuqiao site and Hemudu site. The bridge-shaped Huang first appeared in Majiabang culture (马家浜文化), and was common in Songze Culture (崧泽), then was prevalent in Beiyinyangying site and Lingjiatan site. The half-Bi shaped Huang emerged in early Songze Culture, then became the major shape of Huang in late Liangzhu Culture, then further turned into ritual objects, and finally produced half-Bi shaped Huang with holy face ornamentations. The fan-shaped Huang was common in middle and upper reaches of Yellow River about 4,300 years ago, especially for Shanxian Miaodigou (陕县庙底沟) site in Henan, Changan Fengxi (长安泮西) site in Shanxi, Shimao (石峁) site in Shenmu, Lushanmao (卢山峁) site in Yan’an, Linfen Xiajin (临汾下靳) in Shanxi, Tao

\footnotetext{
${ }^{23}$ Yang Jing, Archaeological Exploration of Prehistoric Jade in China, Peking: Social Scientific Academic Press, 2011, pp. 140-183.

${ }^{24}$ Wang Wei, An Study on Jade Huang Unearthed of Chinese Neolithic Age, Master Thesis of Archaeology and Museum, School of Social Development, Nanjing Normal University, 2007, p. 40.

${ }^{25}$ Huang Jianqiu, \& Lin Liugen, A Study on Serrated-edge Huang In Lingjiatan site. In Yang Jin, Jiang Weidong (Eds.), Yuhun GuoPo: Collected Works about the Relationship Between Chinese Ancient Jade and Tradition Culture (V), Hangzhou: Zhejiang Ancient Books Press, 2012, pp. 93-102.
} 
temple (陶寺) site in Xiangfen, etc. It usually appeared as a set of Huangs consisting of a Bi-shaped ring, which pass on down to Shang and Zhou Dynasties. The Huang with two dragon's heads on both ends was not the standard structure until Zhou Dynasty, and was handed down to Han Dynasty (see Figure 6).

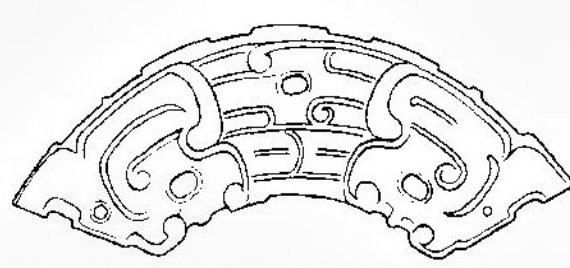

山西晋侯墓地M31出土西周双龙首璜

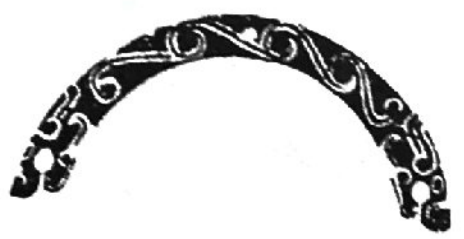

吴县严山王陵出土春秋晚期玉璜

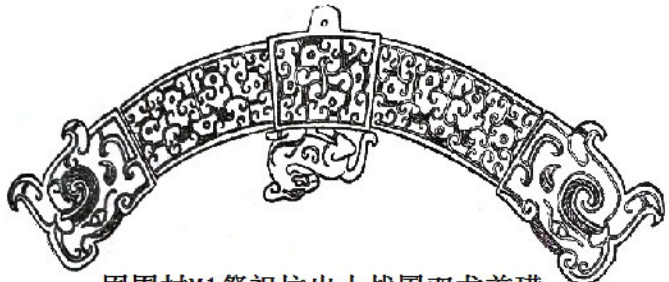

固围村M1祭祀坑出土战国双龙首璜

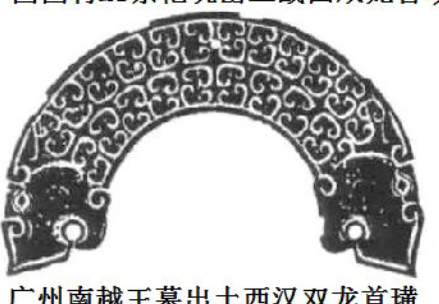

Figure 6. The typical Jade Huang from West Zhou to West Han.

As for the function of Huang, the records in texts mainly concentrate on these aspects: (1) The core objects of wearing jade, which often used to rectify oneself and cultivate ones moral, to symbolize one's social status in the Book of Rites (礼记) and Guo Yu (国语). It is also used to reach the heaven, simply by wearing Huang in Mountains-Seas Book (山海经), and to sacrifice to gods or ancestors in Chu Bamboo slips (楚简); (2) Sacrificial and ritual vessels, such as sacrifice to North with Black Jade Huang (玄璜礼北方) in Rites of Zhou (周礼), the supreme Jade Huang belongs to the Emperor in the Book of Rites (大璜者天子之器也); (3) Credential for dispatching troops (璜以发众) in The Commentaries on Spring and Autumn of Gong Yanggao (春秋公羊传); (4) Auspicious semiotic omens in Taiping Imperial Encyclopaedia (太平御览); (5) A decoration on the bed-curtain in The Songs of Chu (楚辞). The function of Huang from the early classics constitutes the basis of etiquette civilization, providing the source and archetype of literature image in later period.

What is the function of Huang in prehistoric period? One of the clues for the question is the place of excavation. Prehistoric jade were primarily placed on the neck and chest (see Figure 7). At first, the single Jade Huang was popular in Yangtze River delta plain. Then Huang appeared in the set of different jade ornaments like Jade Bead, Jade Bi, etc. In the early and middle stage, it often appeared in female tombs. In the late stage, it often appeared in male tombs. The standard of the tomb was often in proportion the amount of Huang and the quality of the jade material, obviously with the purpose of manifesting the power and the social position of its owners. $^{26}$

\footnotetext{
${ }^{26}$ Yang Jing, Summarize on Huang Unearthed from Lingjiatan Tombs, in Yang Jing, \& Jiang Weidong (Eds.), Yuhun GuoPo: Collected Works about the Relationship Between Chinese Ancient Jade and Tradition Culture (V), Hangzhou: Zhejiang Ancient Books Press, 2012, pp. 67-81.
} 

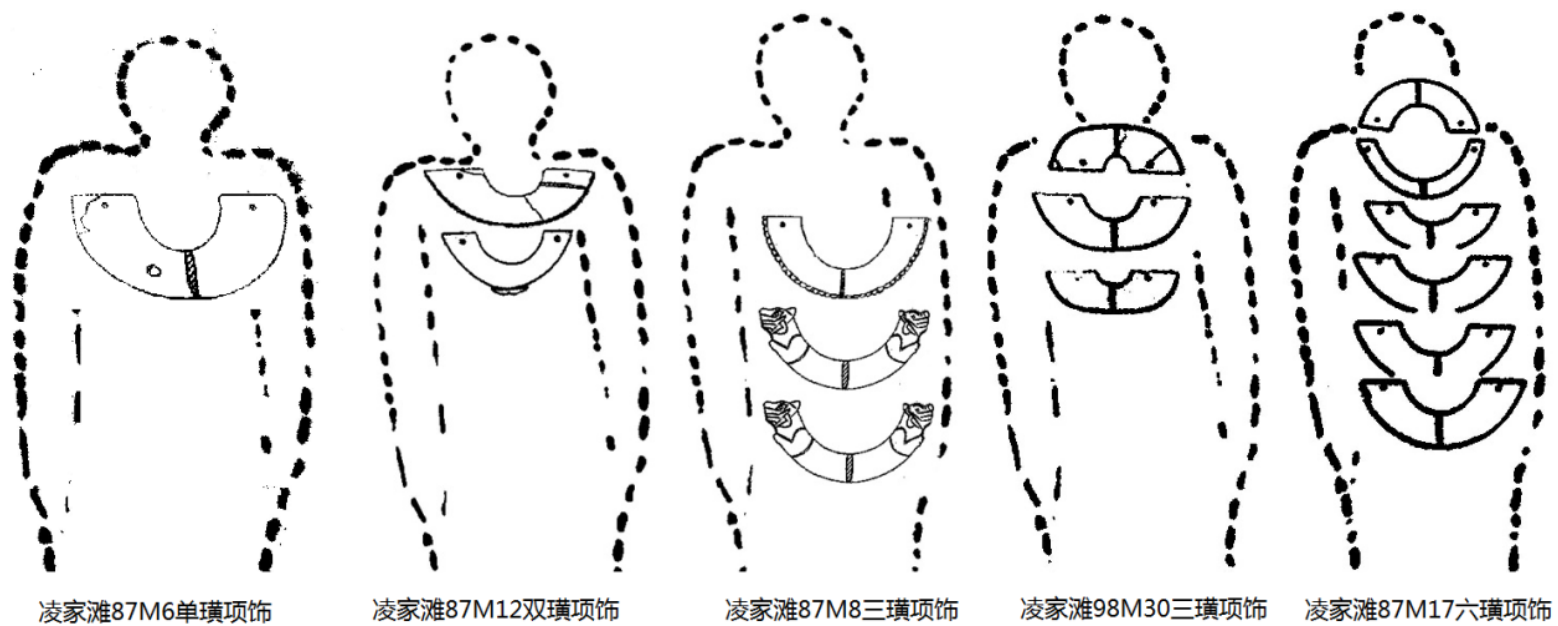

Figure 7. The drawing of wearing Jade Huang in Lingjiatan culture site. Source: Adapted from Yang Jing, Jiang Weidong (2012, pp. 67-81).

Lingjiatan site has the most Huang with abundant shapes and functions. So far there are 147 Huangs of half-ring shape, bridge-shape, half-Bi shape, serrated-edged shape, bird-head shape, tiger-head shape, etc., also with different styles and made with different materials like agate, chalcedony, hopfnerite, actinolite, taxoite, quatz, etc. They were often made of local materials, and differ from site to site. The bird-head and tiger-head Huang were often used in sets, 16.5-18.6 cm long, some of them even could reach $33 \mathrm{~cm}$, which were very likely to be the objects belonging to the emperor, the symbol of coalition or the auspicious omens for marriage or troops (see Figure 8). ${ }^{27}$

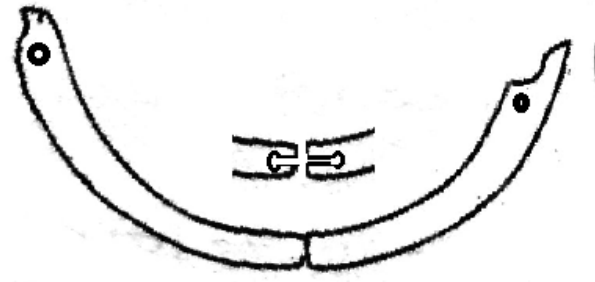

安徽凌家滩M9出土龙风首合符璜

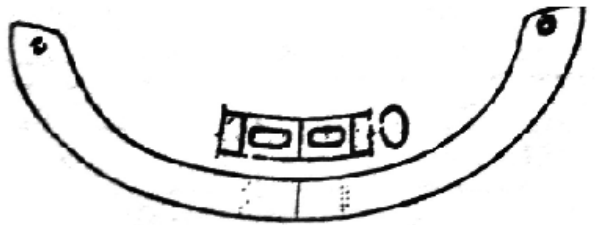

南京北阴阳营M191出土合符璜

Figure 8. The drawing of combination of Jade Huang in Neolithic era.

\section{Awarding Jade and the Policy of Multinational Country: The Start of the Myth of Huang of Xiahoushi}

Among the genealogy of Sage King recorded in texts, the Kings Yao (尧), Shun (舜), Yu (禹), Tang (汤), Wen (文) are the representatives of the Sage King in the four dynasties of Yu, Xia, Shang and Zhou (虞夏商 周). Every sage king ascend the throne would be awarded an auspicious semiotic objects from the god. This imperial object was made of high-quality jade. For example, Shun has “five types ritual jade” (五瑞), Yu has “Black jade gui” (玄圭), Shang Tang has “the supreme Qiu Jade” (大球) to take over power, Wen Wu has “jade gui by auspicious bird” (赤乌衔圭) to launch revolution, Zhou Gong Dan has “Huang of Xiahoushi” (夏 后氏之璜) as the seal of the state. The "Huang of Xiahoushi” was the object granted by the Sage King to show

\footnotetext{
27 Yang Lixin, Pilot Study on Huang Unearthed From Hanshan Lingjiatan Site, In Yang Jing, \& Jiang Weidong (Eds.), Yuhun Guopo (V), pp. 82-91.
} 
his virtue, to make subordinates all over the world surrender. As recorded in The commentaries on Spring and Autumn of Zuo Qiuming (春秋左传), in March four year of Ding Gong (定公), Ding Gong met with all the seigneur to plan the war with Chu in Zhaoling (召陵). During this meeting, a contention took place between clansmen and alien races. So Prince of Song, Zi Yu (子鱼), took the tradition of the award of jade artifacts to explain and resolve disputes: After Emperor Wu had conquered Shang, Emperor Cheng stabilized the country and guard the Zhou by vassal state through selecting and appointing worthy persons, and the system of enfeoffment. As the Emperor Wu's brothers and sons and excellent persons, Zhou Gong Dan was awarded fief Lu and treasures such as splendid carriage (大路), dragon flap (大旂), Jade Huang of Xiahoushi (夏后氏之璜), the best Bow of Fengfu (封父之繁弱), Kangshu was awarded fief Wei and treasures such as splendid carriage (大路), finest silk (少帛), red flags (綪茷, 旃旌) and the great bell (大吕), Tangshu was awarded fief Tang and treasures such as splendid carriage (大路), best-known Drum from Mixu (密须之鼓). They managed respectively the territory and people of Xia and Shang. As the prime minister, Zhou Gong was the greatest sage and contributor to stabilize the social order of early West Zhou Dynasty. So he was awarded treasures such as Jade Huang of Xiahoushi, which originally belongs to the emperor. The meaning of the story was discussed by Ziyu to the king's strategy of governing the country, and more clearly, presented in Lv Ao of Zhou Shu (周书·旅 獒): After Emperor Wu won the battle with Shang, he opened the road to many other national countries. The western country tribute a mastiff which triggered Tai Bao Zhao Gong's writing of $L v$ Ao to persuade Emperor Wu. Zhao Gong said: The enlightened king would lay emphasis on virtue, thus other nations around would acknowledge alliance to him. No matter it was near or far away, they should tribute local products like cloth, food and implements. Thus Emperor declared publicly his benevolent rule to the gentiles in order to make them obedience, and rewarded precious jade to kin nations, with the purpose of showing family bond. As in the annotation: The precious jade was Huang of Xiahoushi which emperor allocate to Lu Gong. This is the basic state policy to sedate the relative courtier by the precious treasure. ${ }^{28}$

Thus "Huang of Xiahoushi" turned into the symbol of precious jade, great virtue, and the ritual vessels of the emperor. According to Ming Tang wei (明堂位) in The Book of Rites, Chong Ding (崇鼎), Guan Ding (贯 鼎), Great Huang (大璜), Feng Fu Gui (封父龟), all these are the emperor’s implements. Zheng Xuan explains that Chong, Guan, Feng Fu are all the name of a nation. The great Huang is the Huang of Xiahoushi. Xia means great. The implements as shown in above listing were passed down by the former dynasty and all collected in Zhou's treasury. The function of these implements were similar to those precious jadeware: Da Yu (大玉), Yi Yu (夷玉), Tian Qiu (天球), Yue Yu (越玉), Chen Bao (成宝) in Guming of Book of History (尚书·顾命), which Zhou Kang Wang used to show his virtue and power, to make subordinates all over the world surrender. Having this kind of precious jadeware means possessing divine power. For this reason, the precious jade implements were targets of struggle and thus occupied by different groups of people during the Spring and Autumn period. For example, In the fifth year of Ding Gong (定公), Ji Pingzi (季平子) appropriate the jadeware Yu Pan (玛璠) to himself what rightfully belongs to Lu Zhao Gong regardless of etiquette. In the eighth year of Ding Gong, Yang Hu, the retainers of Ji, betrayed his master and stole the Jade Huang of Xiahoushi and the Bow of Fengfu and then returned it when he lost the battle in the ninth year of Ding Gong. But subsequently the jade seemed to be lost until in the fourteenth year of Ai Gong (哀公十四年, 公元前481 年), Song Xiangtui (宋向魁), the ruling minister of Song, got away from Cao (the affiliated state of Song) to

${ }^{28}$ Kong Anguo, \& Kong Yingda, Exegesis on the Books of History, Shanghai: Shanghai Ancient Books Press, 2007, pp. $485-487$. 
Wei after the failure in the warfare, however, Gongwen (公文氏), the minister of Wei attacked him for the Huang of Xiahoushi. Tui gave him another jade instead then run to Qi. ${ }^{29}$ Historical documents of this kind illuminate how important Huang of Xiahoushi is. A historian Cheng Gongyue, later commentator of Spring and Autumn Annals said: "Lu is the home to the Huang of Xiahoushi and Bow of Fengfu, the treasures of Emperor Wu, which were awarded to Zhou Gong and guarded by his offsprings to show the respect to ancestor's virtue. The treasures handed down from ancestral monarch such as precious jadeware of Gui (圭), Bi (璧), Wan (琬), Yan (琰), Tian Qiu (天球), Bow and Arrow (弓箭), Dragger-axe (戈) etc. are symbols of special power, so the owner must be defended it. However, in pace with the King of Lu who lost his real authority, the capability to defend treasures and state then disappeared."30

In ancient China, history was written according to the golden rule called Chun Qiu Bi Fa (春秋笔法, a style of writing in which sublime words with deep meaning are used). Although Huang of Xiahoushi was lost due to the frequent transformation of its ownership, the wording itself became a metaphor that was hard to forget. It was still vivid in the poems and history contents. Furthermore, Huang of Xiahoushi became the symbol of the king's virtue, ${ }^{31}$ a prototype of the myth traced by the following literati. Su Shi (苏轼), the famous poet in Song Dynasty for instance, once put it in his essay of inscription on tablet in Jun Ling King's temple (峻灵王庙碑): In ancient time, empire and vassal state all have their treasures, such as West Zhou Dynasty has the best jadeware Wan Yan (琬琰) and great Yu (大玉, may be from Xia or Huashan), Lu has Jade of Xiahoushi, All of which were used to guard the country and to protect their people.

\section{Huang of “Xiahoushi”: Was It Just a Myth?}

Xiahoushi, the imperial kinsmen of Xia Dynasty, had the famous emperor like Yu (禹), Qi (启) and Jie (桀). As the emperors, their similarity was that they were all related to the myth of jade. Both Xia Qi and Xia Jie were related to the myth of Huang. According to Qu Yuan's Tian Wen (天问): Xia Qi got the heavenly music Jiu Bian (九辩) and Jiu Ge (九歌) during his visit to paradise. ${ }^{32}$ But the problem is how could Qi could get to the heaven and obtained the music? Mountains-Seas Book (山海经) gave us the clew:

After the grand ritual by Songs and Dances, Xia Qi who had a god umbrella (疑) in his left hand while hold a jade-huan (玉环) in his right hand with a jade-huang (玉璜) on his chest, flew to the Heaven by riding two dragons. Qi had visited the Emperor of the heaven for three times and got the songs Jiu Bian and Jiu Ge.

This myth could be the detailed annotation to Tian Wen (天问). Qi got to the heaven because of the magic implements such as dragons, snake, Jade Huang (玉璜), jade-huan (玉环), god umbrella (矫). The shape of Huang resembles dragon, snake and rainbow, and the rainbow happens to be the bridge between the heaven and man. $^{33}$

According to ancient myths, the highest objects such as mountains, trees, tower, and hathpace are all the way to heaven. An interesting coincidence is that Xia Qi has ridden on dragon to heaven from Xuan Tai (乘龙

\footnotetext{
${ }^{29}$ Hong Liangji, Explaination on Zuo Qiuming's commentaries of Spring and Autumn Annals, Peking: Zhonghua Book Company, 1987, pp. 828-830, 878.

${ }^{30}$ Cheng Gongyue, Commentator of Spring and Autumn Annals, vol, 39, Qin Ding Si Ku Quan Shu·Jingby V.

31 Wang Liqi, Interpretation on Wenzi, Peking: Zhonghua Company, 2000, p. 484.

32 Jin Kaicheng, \& Dong Hongli, Collation and Annotation of Qu Yuan’s Works, Peking: Zhonghua Book Company, 1996, p. 338, 368.

33 Ye Shuxian, Dragon-Huang-Rainbow: The Myth of Heaven-man Unit and the Root of Chinese Cultural Identity, China Reading Weekly, 2012-03-21(005).
} 
载驱璿台之上, 玷台, a kind of building similar to Babel, built of jade or beautiful stones) according to the Selected Works of ZhaoMing (昭明文选). Moreover, according to the Bamboo Annals (竹书纪年), Xia Qi has banqueted vassals at Xuan Tai, and Xia Jie, the last king of Xia Dynasty, has cost much to build the Qing Palace (倾宫), and decorate the Yao Tai (瑶台, building similar to Xuan Tai), construct Qiong Room (琼室) and Jade door (玉门). Qu Yuan raised a question: Huang Tai was ten-layered high, who could get there? (璜台 十重, 谁可极焉?) Here “Huang Tai” also is a kind of building similar to Xuan Tai, a palace building of jade or a kind of beautiful stone. It was believed that Xia Qi, Xia Jie, Zhou (商纣), Jian Di (简狄), Nv Wa (女娲) all are likely to be the owner of Huang Tai. However, it is important that what made the emperors cost so much to build these luxury buildings? The reason is that they believed they could get closer to the heaven by this.

But What Huang Tai (or Xuan Tai or Yao Tai) looks like? People have been imagining it for thousands years. The discovery of the 4,000,000 $\mathrm{m}^{2}$ stone city of Shimao in Shenmu about 4,000 years ago, especially, the archaeologists found jade shovel, Huang and pieces of Huang within east door-walls in 2012, which provided valid image for the Huang Tai, Xuan Tai in the myth. ${ }^{34}$ And the history period of Stone City in Shi Mao was close to Xia Dynasty in the myth. These could not be a coincidence.

Why the Huang was in the Stone City? Why did people have to wear Huang or Huan to get to heaven? To answer this question, one needs to get a closer look at the function of jade around the world. Jade is the residence for the holy soul and the symbol of god. As the world's earliest Sumerian epic Enmeika alata kingdom put it: Let them extract lazurite from ashlar. Let the gloss of lazurite build a holy mountain in Uruk to be your shelter or a holy temple from the heaven. Let him build an Eanna temple in Alata to be your home. Dong Ba Jing (东巴经) of Naxi (纳西族) also depicted the earth-mother wearing jade-beads, turquoises necklace. Offering turquoises stone to serve the heaven, while she offered gold stone to serve the ground...offered 360 stones in total to perform the ceremony in order to pacify the ghost, to clarify the evil, and to assuage the disaster. The bamboo slips of Chu unearthed from the tombs in Bao Shan (包山), Wang Shan (望山), Tian Xing Guan (天星观), Xincai (新蔡) once recorded Chu used the jade to serve ancestors and gods. Chinese poetry often used Huang to symbolize gods, it is fixed in the collective memory that jade is more or less synonymous to the gods. For example, poet Change Jian of Tang Dynasty wrote in his poem Gu Yi (古意): “I have dreamed of a goddess who wears gold veil and jades.” Poet Cui Shu (崔曙) wrote in his poem Call on Qi's mother with his colleagues (同诸公谒启母祠): The spring breeze clink the jades, while the rain in the afternoon wet the cloth (春风鸣玉佩，暮雨拂灵衣。).

The remaining problem is whether does the Huang of Xiashoushi refers to all the jade ornaments of Emperor Xia in general, or just in particular to the Jade Huang which Qi wore it in his visiting to heaven? What does the Huang of Xiahoushi granted to Zhou Gong and hidden in Lu Palace look like? After Yang Hu and Xiang Tui, who owned the Huang? We still find no exact answer for the question. Could such 7,000-year history of Huang trace Emperor Xia's wearing Jade Huang? According to historians and archaeologists, Xia Dynasty is believed to be about 4,070-3,600 years ago, roughly the equivalent of the stage from the late period of Shimao (石峁), Xinhua (新华) and Taosi (陶寺) cultural sites to the early period of Erlitou (二里头) Culture, more than 800 jade artifacts were found in these sites, with the salient features as follow: First, the type and shape of the jade of different site indicate a trend of multiple fusion. Second, the most eye-catching jade is big

${ }^{34}$ Ye Shuxia, Theory of Jade Culture Take the Lead in Unit Chinese: New Discovery of Shimao Jade and its civilization significance, Ethnic Arts Quarterly, 2013(4), 11-20. 
Jade Knife (玉刀), Jade Zhang(玉璋), Jade Yue (玉钱), Jade Ge (玉戈), whose types all seem similar. Third, the types of Huang of this period were less than 6,000-4,500 years ago, even less than middle and late West Zhou. However, the tradition of jade Bi (disc) consisted of three or five fan-shaped-Huang passed down. For example, more than 10 pieces of Huang discovered in Shimao site indicated a trend of unification in shape and structure despite its transforming from broken Bi. More than 120 pieces of jade in Erlitou Cultural Circle from about Late Xia Dynasty were still like this (see Figure 9). ${ }^{35}$ Nevertheless, the Huang of Xiahoushi, which could be regard as the emperor's imperial object, were hard to find.

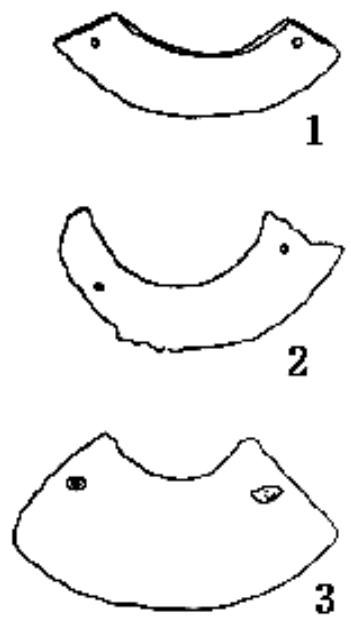

石峤古城玉璜

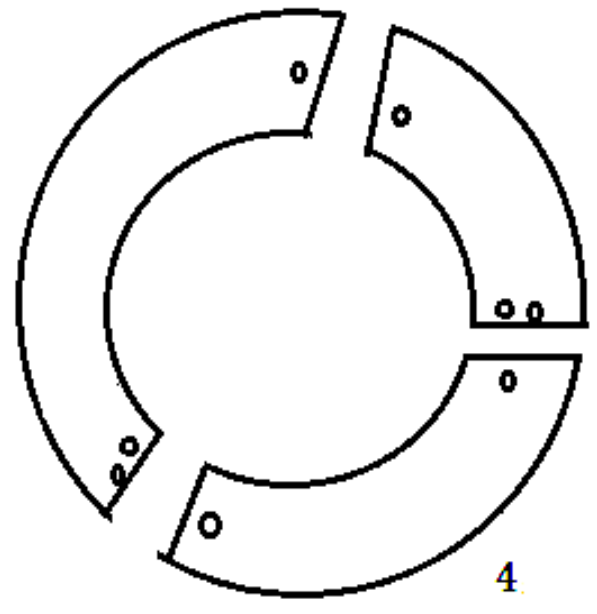

赛汾陶寺联璜璧

Figure 9. The drawing of Jade Huang about 2,000 B.C.

About more than 100 pieces of Huang were discovered in Yin Xu (殷墟), most of which are one-third of a circle shape, and a few of them are half or quarter of a circle. Those delicate ones are dragon or fish shaped. ${ }^{36}$ The well-preserved imperial kinsman’s tomb in middle and late West Zhou Dynasty, like Guo (虢) and Jin (晋) collected well-carved Huang sets. Since middle west Zhou Dynasty, Zhou people sought to differentiate themselves from the previous Shang, by means manufacturing and speech, forging themselves as the true successor of tradition. According to the same records of inscription in Sui Gong Xu (遂公昷), Qin Gong Gui (秦公篮), Shu Yi Zhong (叔夷钟), The Book of Songs (诗经) and The Book of History (尚书), historian proved that the myth about Xia and Yu (禹) had already existed since middle West Zhou Dynasty. The discovery of Sui Gong Xu (遂公徂) not only moved up the history of Yu preventing floods to 600-700 years earlier but also indicated the idea that Xia was the first one of the three dynasties had already existed since middle West Zhou. ${ }^{37}$ Therefore, scholars consider that the existence of Xia as the key factor for Chinese Identity. The great King Yu and his son Qi are the founders of Xia Dynasty, which means that there would be no Xia or China without Yu and Qi.

\footnotetext{
35 Zhu Naicheng, Glimpse at Jade of Xia Pieriod, in Yuhun Guopo: Exhibition of Jadeware, Jade culture and Chinese Civilization of Xia Dynasty, Hangzhou: Zhejiang Ancient Books Press, 2013, pp. 12-65.

${ }^{36}$ Insititute of Archaeology of Chinese Social Science (Ed.), The Tomb of Fu Hao in Yinxu, Peking: Cultural Relics Press, 1980, p. 131.

${ }^{37}$ Li Xueqin, The Study on SuiGong Xu and its Significance, Journal of National Museum of China, 2002(6), 5-12.
} 


\section{Conclusion}

The Huang of Xiashoushi was the great implement allocated to Zhou Gong by Emperor Wu after they won the battle. This was the evidence for that the myth of Huang of Xiahoushi started from early Zhou Dynasty and was prevalent in late Spring and Autumn and then become the story spread. What's the subtle relation between these? What's the meaning of the reappearance of Xia Yu and Huang of Xiahoushi? These are questions yet to be answered, and obviously more evidence are waiting to be explored in the future.

Although it is highly debatable whether Xia Dynasty or the Huang of Xiahoushi really existed or not, memory and story about it is abundant. The Huang functions as the holy implement in the system of virtue, and Huang of Xiahoushi could be regarded as the very symbol of Chinese identity.

\section{References}

Colin Renfrew. (2009). Prehistory: Memory of Human Mind. (Zhang Mingling, Trans.). Taipei: Owl Press.

Duan Yucai. (1981). Annotation on Shuowenjiezi. Shanghai: Shanghai Ancient Books Press.

Guan Xiaoyun, \& Wang Honggang. (2010). Investigation of Shaman Culture's remains in Oroqen People. Peking: Nation Press.

Guo Moruo. (1954). Explanations on Bronze Inscription. Peking: People Press.

Hong Liangji. (1987). Explaination on Zuo Qiuming's commentaries of Spring and Autumn Annals. Peking: Zhonghua Book Company.

Huang Dekuan. (2007). 古文字谱系疏证 (Anotation on the Geneology of Ancient Characters). Peking: Commercial Press.

Huang Yaping, \& Meng Hua. (2001). Chinese Character Semeiology. Shanghai: Shanghai Ancient Books Press.

Insititute of Archaeology of Chinese Social Science. (1980). The Tomb of Fu Hao in Yinxu. Peking: Cultural Relics Press.

Jin Kaicheng, \& Dong Hongli. (1996). Collation and Annotation of Qu Yuan’s Works, Peking: Zhonghua Book Company.

Kong Anguo, \& Kong Yingda. (2007). Exegesis on the Books of History. Shanghai: Shanghai Ancient Books Press.

Li Fang. (1994). Taiping Imperial Encyclopaedia. Shijiazhuang: Hebei Education Press.

Li Xueqin. (2002). The Study on SuiGong Xu and its Significance. Journal of National Museum of China, 6.

Liu Baonan. (1990). The Analects of Confucius. Peking: Zhonghua Books Company.

Pei Wenzhong. (2002). The Culture of Zhoukoudian Upper Cave Man. Wenwu Chunqiu, 2.

Ren Jifang. (1992). Chinese Etymology. Chongqing: Chongqing Press.

Research Centor of Chinese Jade Culture. (2013). Yuhun Guopo: Exhibition of Jadeware, Jade culture and Chinese Civilization of Xia Dynasty. Hangzhou: Zhejiang Ancient Books Press.

Ruan Yuan. (2003).Commentaries on Thirteen Classics. Peking: Zhonghua book company.

Sun Qingwei. (2008).The Studies on the Rule of Jade Using in Zhou Dynasties. Shanghai: Shanghai Ancient Books Press.

Tang Lan. (1995). Tang Lan’s Selected Works about Bronze Inscription. Peking: ZiJinCheng Press.

Tang Qicui. (2011). Body and Etiquette: Practicing Etiquette by Wearing Jade and Confucian Myth. The Journal of Bai Se College, 3.

Tang Qicui. (2012). The Ritual Relics and the New Evidence of the Historian Recording Ancestry: The Sorcery-History Roots of Confucianism and Taoism from the Myth of YuGui. The Journal of Philosophy and Culture, 6.

Tang Qicui. (2014). Etiquette. Ethnic Arts Quanterly, 3.

The Institution of Archaeology of Zhejiang Province. (1997). Neolithic Sites in XiaoShan Kuahuqiao. The Journal of the Institution of Archaeology of Zhejiang. Peking: ChangZheng Press.

The Institution of Archaeology of Zhejiang Province. (2003). Hemudu: Report on Archaeological Excavations of Neolithic Site. Peking: Cultural Relics Press.

Wang Guowei. (2006). 观堂集林 (Selected Works of Wang Guowei). Peking: Zhonghua Book Company.

Wang Liqi. (2000). Interpretation on Wenzi. Peking: Zhonghua Book Company,2000.

Wang Pinzhen. (1983). Commentaries on the Book of Rite of Dai De. Peking: Zhonghua Book Company.

Wang Wei. (2007). An Study on Jade Huang Unearthed of Chinese Neolithic Age (Master thesis of Archaeology and Museum, School of Social Development, Nanjing Normal University).

Xia Nai. (1983). The Classification, Denominate and Function of Jadeware of Shang Dynasty. Archaeology, 5.

Yang Jing. (2011). Archaeological Exploration of Prehistoric Jade in China. Peking: Social Scientific Academic Press. 
Yang Jing, \& Jiang Weidong. (2012). Yuhun GuoPo: Collected Works about the Relationship Between Chinese Ancient Jade and Tradition Culture (V). Hangzhou: Zhejiang Ancient Books Press.

Ye Shuxia. (2013). Theory of Jade Culture Take the Lead in Unit Chinese: New Discovery of Shimao Jade and its civilization significance, Ethnic Arts Quarterly, 4.

Ye Shuxian. (2012). Dragon-Huang-Rainbow: The Myth of Heaven-man Unit and the Root of Chinese Cultural Identity. China Reading Weekly, 03-21(005). 